\title{
APPLICATION OF A CONTINUOUS RAINFALL-RUNOFF MODEL TO THE BASIN OF KOSYNTHOS RIVER USING THE HYDROLOGIC SOFTWARE HEC-HMS
}

\author{
KAFFAS K.* \\ HRISSANTHOU V.
}

\author{
Department of Civil Engineering \\ Democritus University of Thrace \\ 67100 Xanthi, Greece
}

Received: 30/08/2013

Accepted: 03/01/2014 *to whom all correspondence should be addressed: e-mail: kostaskaffas@gmail.com

\begin{abstract}
In this paper, the application of a continuous rainfall-runoff model to the basin of Kosynthos River (district of Xanthi, Thrace, northeastern Greece), as well as the comparison of the computational runoff results with field discharge measurements are presented. The rainfall losses are estimated by the widely known Soil Conservation Service-Curve Number model, while the transformation of rainfall excess into direct runoff hydrograph is made by using the dimensionless unit hydrograph of Soil Conservation Service. The baseflow is computed by applying an exponential recession model. The routing of the total runoff hydrograph from the outlet of a sub-basin to the outlet of the whole basin is achieved by the Muskingum-Cunge model. The application of this complex hydrologic model was elaborated with the HEC-HMS 3.5 Hydrologic Modeling System of the U.S. Army Corps of Engineers. The results of the comparison between computed and measured discharge values are very satisfactory.
\end{abstract}

KEYWORDS: Continuous rainfall-runoff model; Kosynthos River; Soil Conservation Service; Muskingum-Cunge model; HEC-HMS.

\section{INTRODUCTION}

In this paper, the application of a continuous rainfall-runoff model to the basin of Kosynthos River (district of Xanthi, Thrace, northeastern Greece), as well as the comparison of the computational runoff results with field discharge measurements are presented.

First simulation efforts of the rainfall-runoff process are observed in the second half of the $19^{\text {th }}$ century. At the duration of this period, most engineers used either empiric types or the rational method, which can be characterized as the first rational approach of the "flow forecast" problem from rainfall data given (Dooge, 1957; Dooge, 1959).

Nevertheless, most historical developments in the field of rainfall-runoff modeling occurred in the first half of the $20^{\text {th }}$ century. During the decade 1920, when the need for a corresponding type which would be used for bigger basins, became perceptible, a lot of modifications were imported into the rational method in order to cope with the nonuniform distribution, in space and time, of the rainfall and the characteristics of the basin. The decade of the 1930's experienced an outburst on all fronts of hydrology (Džubáková, 2010). In 1932, Sherman introduced the concept of unit hydrograph, which is based on the principle of succession. This method was dominative in hydrology for more than 25 years. However, the succession principle includes a lot of assumptions and problems; for example, the basin behaves as a linear, temporally immutable system in relation with the rainfall and its transformation into surface flow, the segregation of the surface flow from the baseflow and the determination of effective rainfall. One year later, in 1933, the Hortonian infiltration theory was imported by R. E. Horton. Robert E. Horton is best known as the originator of the infiltration excess overland flow concept for storm hydrograph analysis and prediction, which, in conjunction with the 
unit hydrograph concept, provided the foundation for engineering hydrology for several decades (Beven, 2004).

Significant progress in the simulation of the processes took place in 1950's, when hydrologists found techniques, like the Laplace transformations or Fourier series, which changed the linear, immutable basin into a dynamic system. Thus, the base was set for the development of the first conceptual models, based on the principles of hydraulics. For the discretization of the unit hydrograph, simplified differential equations were used, as the one that describes the storage behaviour of a reservoir or cascade of reservoirs as interrelation of time (Prasad, 1967). Thus, the unit hydrograph was described with parameters that could be estimated from the basin characteristics or with statistical terms, as propensities of regression and method of maximum likelihood. The determination of unit hydrograph form from real data, only with the use of transformations, was not satisfactory, but with the import of restrictions of continuity and regularity became more realistic and satisfactory (Wiener, 1949; Tikhonov, 1963; Eagleson et al., 1965; Todini and Wallis, 1977).

An extensive acceleration of new discoveries in rainfall-runoff modeling emerged with a digital revolution in 1960's, when the development of models has gone hand-in-hand with increase of computing power. Thanks to new technologies, modellers' focus was shifted from event-based models (originated from the 1930's) to the first hydrologic models for continuous simulation of rainfall-runoff processes (emerging in the 1960's with computing power) (Sharma et al., 2008, in Džubáková, 2010). Additionally, in the 1960's, due to technology advances, conceptual modeling first came to light. One of the first conceptual models is the Stanford Watershed Model (SWM) developed by Crawford and Linsley in 1966. It was one of the first models trying to model virtually the entire hydrologic cycle (Frevert and Singh, 2006).

In the 1970's and 1980's, the need of a more realistic approach of the process of rainfall-runoff, based on physiographic characteristics (i.e. land use, soil cover and slope) in complex larger basins, was urgent. Thus, physically-based hydrologic models were developed. These models embody components such as surface runoff, evapotranspiration, and channel flow, but they can be far more complex. In a nutshell, physically-based models, also known as deterministic, comprehensive or process-based models, try to represent the physical processes observed in the real world.

Later on, number of physically-based watershed hydrology models were constructed, e.g. Storm Water Management Model (SWMM), Precipitation-Runoff Modelling System (PRMS), National Weather Service (NWS) River Forecast System, Streamflow Synthesis and Reservoir Regulation (SSARR), Système Hydrologique Européen (SHE), TOPMODEL, Institute of Hydrology Distributed Model (IHDM) and others (Frevert and Singh, 2006, in Džubáková, 2010).

One basic part of the rainfall-runoff process is the flood routing. Regarding flood routing, the models can be divided into two main categories, the hydrologic models as the Muskingum model (Dooge et al., 1982) and the hydraulic models as the kinematic, diffusion and hydrodynamic wave models (Price, 1973; Keefer and McQuivey, 1974).

The rainfall-runoff models are classified into various categories that depend on the kind of the equations, the time and spatial step etc. The most common categories of the models are the continuous and event models, as well as the lumped and distributed models. Continuous simulation of streamflow is useful for predicting the streamflow impacts of land use changes and stormwater management practices (McEnroe, 2010). However, the simulation of single rainfall events in a continuous hydrologic model is similar with the respective simulation in event-based models.

In the present study, a continuous distributed model was applied to a relatively large basin (237 $\mathrm{km}^{2}$ ). Very important for a continuous hydrologic model is the simulation of time variation of baseflow during and after the rainfall events. An exponential recession model was used as baseflow model in this study, which is the novelty of the present paper, because, usually, simple assumptions are made for the time variation of baseflow (e.g. constant monthly value of baseflow).

The deterministic distributed hydrologic model HEC-HMS is used to simulate the flow in the hydrologic units of the watershed. HEC-HMS was conceived as a software-based tool for simulating the hydrologic cycle in the context of engineering problem solving (Scharffenberg et al., 2010). It is designed to simulate the precipitation-runoff processes of dendritic watershed systems and it is applicable in a wide range of geographic areas for solving the widest possible range of problems (USACE, 2010). The US Army Corps of Engineers developed the VISUAL HEC and its evolution the HEC-HMS software, which is used in this paper. 
HEC-HMS has been successfully applied, in its continuous version, in a wide range of cases. Fleming and Neary (2004) successfully used HEC-HMS as a tool for continuous hydrologic simulation in the Cumberland River basin. Chu and Steinman (2009) carried out continuous hydrologic simulations by applying HEC-HMS to the Mona Lake watershed in west Michigan. Neary et al. (2004) applied the HEC-HMS model, with its soil-moisture-accounting (SMA) algorithm for continuous simulation, to compare streamflow simulations using basin-average gauge and basinaverage radar estimates. Cunderlik and Simonovic (2004) used the continuous simulation version of the HEC-HMS model to describe the main hydroclimatic processes in the Ontario River basin.

A brief theoretical model description is given below.

\section{THEORETICAL MODEL DESCRIPTION}

\subsection{Rainfall excess model}

The Soil Conservation Service-Curve Number (SCS-CN) method is widely used in hydrology, especially in precipitation-runoff computer software programs, and it is an effective way of calculating the surface runoff, for a single storm (SCS, 1993). The SCS-CN method for predicting surface runoff volume from rainfall is accepted technology (Nearing et al., 1996). Perhaps, it is the most common method for predicting storm runoff volume. It appears in such models as AGNPS, EPIC, SWAT and HEC - HMS (Walker et al., 2001). The basic assumption of the SCS-CN method is that, for a single storm, the ratio of actual soil retention, after runoff begins, to potential maximum retention is equal to the ratio of direct runoff to available rainfall. According to SCS-CN method, the rainfall excess is computed by:

$Q=\frac{(P-0.2 S)^{2}}{P+0.8 S}$, for $P>0.2 S$, otherwise $Q=0$

where

$Q$ : rainfall excess $(\mathrm{mm})$

$P$ : total rainfall $(\mathrm{mm})$

$\mathrm{S}$ : maximum hydrologic losses $(\mathrm{mm})$

Some different aspects concerning the value of the arithmetic coefficient 0.2 [Equation (1)] are given in Angelidis et al., 2010.

The maximum hydrologic losses are computed by the equation:

$\mathrm{S}=\frac{25400}{\mathrm{CN}}-254$

where $\mathrm{CN}$ is the curve number which can be estimated as a function of land use, soil type and antecedent moisture conditions, using tables published by the SCS. The smaller the $\mathrm{CN}$ is, the smaller the surface runoff is, while the bigger the $\mathrm{CN}$ is, the bigger the surface runoff is $(0<\mathrm{CN}<100)$.

\subsection{Evapotranspiration}

The rainfall losses estimated by the SCS-CN model are mainly due to rainfall water infiltration. Generally, in event-based hydrologic models, the rainfall losses due mainly to infiltration are computed. However, in continuous hydrologic models, the rainfall losses due to evapotranspiration are mainly computed because they constitute the largest part of the rainfall losses on a long-term time basis.

Evapotranspiration is an important component of the water cycle, and is primarily affected by weather and climate conditions. However, there are additional factors affecting evapotranspiration like crop characteristics, management and environmental factors.

For estimating evapotranspiration, Allen et al. (1998) derived the Penman-Monteith FAO-56 (Food and Agriculture Organization) equation from the original Penman-Monteith equation and the equations of aerodynamic and surface resistance. The Penman-Monteith FAO-56 method is now universally accepted for calculating evapotranspiration in various climates (Dinpashoh et al., 2011), and can be expressed as: 
$E T_{0}=\frac{0.408 \Delta\left(R_{n}-G\right)+\gamma \frac{900}{T+273} u_{2}\left(e_{s}-e_{\alpha}\right)}{\Delta+\gamma\left(1+0.34 u_{2}\right)}$

where

$\mathrm{ET}_{\mathrm{o}}$ : potential evapotranspiration of the reference crop $\left(\mathrm{mm} \mathrm{d}^{-1}\right)$

$\mathrm{R}_{\mathrm{n}}$ : net radiation at the crop surface $\left(\mathrm{MJ} \mathrm{m}^{-2} \mathrm{~d}^{-1}\right)$

$\mathrm{G}$ : soil heat flux density (MJ $\mathrm{m}^{-2} \mathrm{~d}^{-1}$ )

$\mathrm{T}$ : mean daily air temperature at height ranging from 1.5 to $2.5 \mathrm{~m}\left({ }^{\circ} \mathrm{C}\right)$

$\mathrm{u}_{2}$ : wind speed at $2 \mathrm{~m}$ height $\left(\mathrm{m} \mathrm{s}^{-1}\right)$

$\mathrm{e}_{\mathrm{s}}$ : saturation vapor pressure at height ranging from 1.5 to $2.5 \mathrm{~m}(\mathrm{kPa})$

$\mathrm{e}_{\mathrm{a}}$ : actual vapor pressure at height ranging from 1.5 to $2.5 \mathrm{~m}(\mathrm{kPa})$

$\Delta$ : slope of the vapor pressure curve $\left(\mathrm{kPa}^{\circ} \mathrm{C}^{-1}\right)$

$\mathrm{V}$ : psychrometric constant $\left(\mathrm{kPa}^{\circ} \mathrm{C}^{-1}\right)$

Further details of the Penman-Monteith FAO-56 method can be found in Allen et al. (1998).

\subsection{Lag time and time of concentration}

There is a delay in time, after a brief heavy rain over a watershed, before the runoff reaches its maximum peak. This delay is a watershed characteristic called lag (Kent, 1972). In order to calculate the lag time, the basin's time of concentration has to be calculated first (Nasri et al., 2011). The concentration time was computed by various empiric equations (Fort Bend (Espey, Huston and Associates,1987); Kerby-Hathaway, 1959; Kirpich-Ramser 1940; Turazza-Giandotti, 1934; SCS, 1993). After the comparison of the computed discharges with the field measurements, it was proved that the most suitable empiric equation is the formula of Turazza-Giandotti and that the model is very sensitive to the concentration time:

$\mathrm{t}_{\mathrm{c}}=\frac{4 \sqrt{\mathrm{A}}+1.5 \mathrm{~L}}{0.8 \Delta \mathrm{H}}$

where

$\mathrm{t}_{\mathrm{c}}$ : concentration time $(\mathrm{hr})$

$A$ : area of the basin $\left(\mathrm{km}^{2}\right)$

$L$ : length of the main stream of the basin $(\mathrm{km})$

$\Delta \mathrm{H}$ : difference between the average basin elevation and the outlet elevation $(\mathrm{m})$

Lag time $t_{p}$ can be estimated in terms of $t_{c}$, using the Soil Conservation Service empiric relation:

$t_{p}=0.6 t_{c}$

\subsection{Model for the transformation of rainfall excess into runoff hydrograph}

The hydrograph of direct runoff is computed on the basis of the theory of unit hydrograph. In the dimensionless synthetic unit hydrograph of SCS (1993), discharges are expressed as a fraction of the peak discharge $q_{p}$ and time steps as a fraction of the rise time of the unit hydrograph $T_{p}$ (Figure 1). A method or formula for the determination of lag time that has a strong influence on the computed peak discharge, should be selected (Daniil et al., 2005). Knowing the peak discharge and the lag time $t_{p}$ for a rainfall excess of specific duration, the unit hydrograph can be estimated by the dimensionless synthetic unit hydrograph for the study basin. 


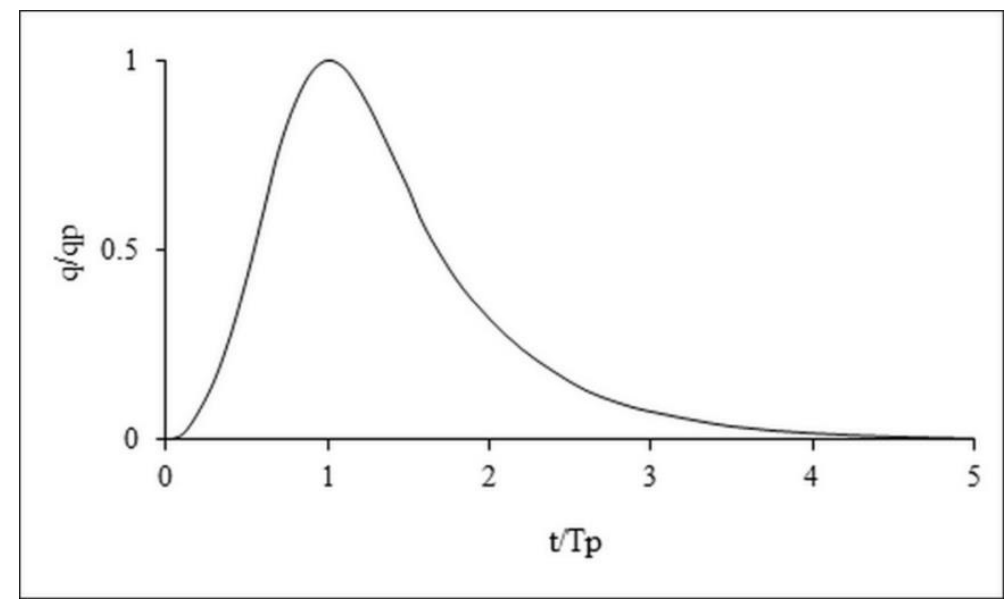

Figure 1. SCS dimensionless synthetic unit hydrograph

The values $q_{p}$ and $T_{p}$ are estimated by a simplified triangular unit hydrograph, where the recession time is equal to $1.67 \mathrm{~T}_{\mathrm{p}}$. The area which is surrounded by the curve of the unit hydrograph must be equal to the rainfall excess of $1 \mathrm{~cm}$. The peak discharge $q_{p}\left(\mathrm{~m}^{3} \mathrm{~s}^{-1}\right)$ is:

$\mathrm{q}_{\mathrm{p}}=\frac{\mathrm{CA}}{\mathrm{T}_{\mathrm{p}}}$

where

$C: 2.08$

A : basin area $\left(\mathrm{km}^{2}\right)$

$\mathrm{T}_{\mathrm{p}}$ : rise time of unit hydrograph $(\mathrm{hr})$

In addition, the studied unit hydrographs in small and large basins show that the lag time $t_{p}$ of the basin is approximately equal to $0.6 t_{c}$, where $t_{c}$ is the concentration time [Equation (4)]. The time $T_{p}$ is a function of the lag time $t_{p}$ and the duration of the rainfall excess $t_{R}$ :

$T_{p}=\frac{t_{R}}{2}+t_{p}$

\subsection{Exponential recession model}

The applied composite model includes an exponential recession model to represent the time variation of baseflow (Chow et al., 1988). The recession model is described mathematically by the following equation:

$Q_{b t}=Q_{b 0} k^{t}$

where

$Q_{b t}$ : baseflow at any time $t$

$\mathrm{Q}_{\mathrm{b0}}$ : initial baseflow (at time zero)

$\mathrm{k}$ : exponential decay constant; it is defined as the ratio of the baseflow at time $\mathrm{t}$ to the baseflow one day earlier.

According to the baseflow model, a threshold value has to be specified as a flow rate or as a ratio to the computed peak flow (Figure 2). Equation (7) is applied twice to a hydrograph: (a) to simulate the initial flow (baseflow) recession; in that case, the value $Q_{b, 01}$ lies on the discharge axis, and (b) to simulate the total runoff recession; in that case, the value $Q_{b, 02}$ corresponds to the point of intersection between the threshold line and the recession limb of the hydrograph (Figure 2). For the subsequent second hydrograph of Figure 2, the value $Q_{b, 03}$ corresponds to the end of the first hydrograph, while the value $Q_{b, 04}$ is defined as the value $Q_{b, 02}$ in the first hydrograph. 


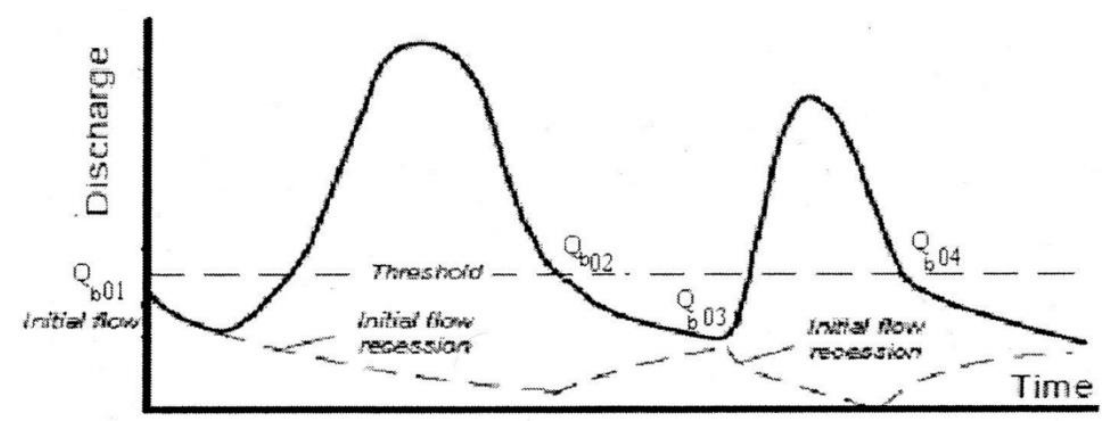

Figure 2. Recession with multiple runoff peaks

\subsection{Routing model of Muskingum-Cunge}

The division of a large basin into sub-basins renders the application of a hydrograph routing model necessary (Angelidis et al., 2010). The routing of the total runoff (direct runoff + baseflow) hydrograph from the outlet of a sub-basin to the outlet of the whole basin is enabled by means of Muskingum-Cunge model.

This model is based on the widely known hydrologic routing Muskingum model, including the parameters $K$ and $x$ that cannot be easily estimated. Parameter $K$ accounts for the translation or concentration portion of the routing, while parameter $x$ accounts for the storage portion of the routing. While Muskingum method constitutes a hydrologic approach to the stream channel routing, Muskingum-Cunge method constitutes a hybrid approach, namely a combination of hydrologic and hydraulic approach.

The basic equation of Muskingum-Cunge model is given below:

$Q_{i+1}^{k+1}=C_{0} Q_{i}^{k+1}+C_{1} Q_{i}^{k}+C_{2} Q_{i+1}^{k}$

where

$Q$ : total runoff discharge

$\mathrm{i}$ : designates the space step $\Delta \mathrm{x}$

$\mathrm{k}$ : designates the time step $\Delta \mathrm{t}$

$C_{0}=\frac{c \lambda-2 x}{2(1-x)+c \lambda} \quad C_{1}=\frac{c \lambda+2 x}{2(1-x)+c \lambda} \quad C_{2}=\frac{2(1-x)-c \lambda}{2(1-x)+c \lambda}$

$\mathrm{K}=\frac{\Delta \mathrm{x}}{\mathrm{C}} \quad \lambda=\frac{\Delta \mathrm{t}}{\Delta \mathrm{x}}$

The product $c \lambda=c(\Delta t / \Delta x)=C$ is called the Courant number and is equal to the ratio of the celerity of small waves $\mathrm{c}$ to the grid celerity $\Delta \mathrm{x} / \Delta \mathrm{t}$.

By equating the hydraulic physical diffusion coefficient $v_{h}=q_{0} / 2 S_{f}$ with the numerical diffusion coefficient $v_{n}=c \Delta x(0.5-x)$ of the numerical scheme, the value of the parameter $x$ is obtained:

$x=\frac{1}{2}\left(1-\frac{q_{0}}{S_{f} c \Delta x}\right)$

where

$c$ : small wave celerity

$\mathrm{q}_{0}$ : reference discharge per unit width (from the inlet hydrograph)

$\mathrm{S}_{\mathrm{f}}$ : energy slope

By using Equation (11), the parameter $\mathrm{x}$ is computed by means of the physical characteristics of the routing stream $\left(\Delta x, S_{f}, c, q_{0}\right)$. 


\section{APPLICATION TO KOSYNTHOS RIVER BASIN}

The above model was applied to Kosynthos River basin (district of Xanthi, Thrace, northeastern Greece) in order to simulate continuous hydrographs of the years 2005-2009. The hydrologic model HEC-HMS 3.5 ran continuously for the period 2005-2009, and more specifically from $1^{\text {st }}$ January 2005 until $1^{\text {st }}$ February 2009. The basin of Kosynthos River has an area of about $237 \mathrm{~km}^{2}$ consisting of forest $(74 \%)$, bush (4.5\%), urban area (1.5\%) and an area with no significant vegetation (20\%) (Figure 3). The dominant rocks are granite-diorite, marble, gneiss-granite and migmatite. The structure of the rocks (low percentage of deep percolation), as well of the soil (semi-permeable) favour a relatively high runoff. The highest altitude of the basin is about $1700 \mathrm{~m}$. The length of the main stream of the basin is about $35 \mathrm{~km}$. For more precise calculations, the basin was divided into ten natural sub-basins (Figure 4). The structure of the basin, especially for the model operation, is depicted in Figure 5. In order to clarify Figure 5, it is exemplarily reported that the main stream of Sub-basin 4 and the Reach 1, which is not the main stream of Sub-basin 1, contribute to Junction 1 (Tsakiridis et al., 2007).

For the estimation of the model parameters, rainfall data (time step $10 \mathrm{~min}$ ) from the meteorological station of Oraio, as well as topographical, geological, main stream and soil cover maps were used. The meteorological station of Oraio is located in the centre of gravity of the basin (Figure 4), at an elevation of $800 \mathrm{~m}$. However, it has to be noted that the rainfall data of only one meteorological station is not representative for the whole basin, especially for the sub-basins located near the outlet of the whole basin.

The climate of the under study area is characterized as temperate mediterranean. The average annual temperature is $14^{\circ} \mathrm{C}$ and about $750 \mathrm{~mm}$ of precipitation fall annually. The Penman-Monteith FAO-56 method was used to estimate the monthly evapotranspiration values, for the under study time periods. Thus, the monthly average method was selected from HEC-HMS. However, the evapotranspiration computed by the method mentioned above is the potential evapotranspiration of the reference crop, which is different from the soil cover of the basin considered. The potential evapotranspiration of a specific crop, $\mathrm{ET}_{\mathrm{c}}$, is calculated as the product of the potential evapotranspiration of the reference crop, $\mathrm{ET}_{\mathrm{o}}$, and the crop coefficient $\mathrm{K}_{\mathrm{c}}$, as outlined in Equation (13) (Doorenbos and Pruitt, 1977; Allen et al., 1998, in Verstraeten et al., 2005):

$\mathrm{ET}_{\mathrm{c}}=\mathrm{K}_{\mathrm{c}} \mathrm{ET}_{\mathrm{o}}$

where

$\mathrm{ET}_{\mathrm{c}}$ : potential evapotranspiration of a specific crop $\left(\mathrm{mm} \mathrm{d}^{-1}\right)$

$E T_{0}$ : potential evapotranspiration of the reference crop $\left(\mathrm{mm} \mathrm{d}^{-1}\right)$

$\mathrm{K}_{\mathrm{c}}$ : crop coefficient

As mentioned above, the considered basin is covered mainly by forest, rather than crop. Doorenbos and Pruitt (1977), in Verstraeten et al. (2005), give $\mathrm{K}_{\mathrm{c}}$ min and max values for a variety of tree species. A value of 0.83 is taken in the current study. The calculated monthly values of evapotranspiration vary between 20 and $125 \mathrm{~mm}$.

Moreover, the Laboratory of Hydrology and Hydraulic Structures, Civil Engineering Department, Democritus University of Thrace, carried out 37 field measurements of discharge near the outlet of Kosynthos River basin (Figure 4), five of which in October, November, December 2005, nine in March, April, May, June, July 2006, 14 in March, April, May 2007, eight in May, June, July, September, November, December 2008 and one in January 2009.

The cross section of Kosynthos River, where the measurements were performed (Figure 4), was divided into subsections, and the mean flow velocity was measured separately in each subsection using an impeller flow meter. The stream discharge in each subsection results as the product of the mean flow velocity and the cross-sectional area of the subsection. The stream discharge of the whole cross section is the sum of the stream discharges of the subsections. 


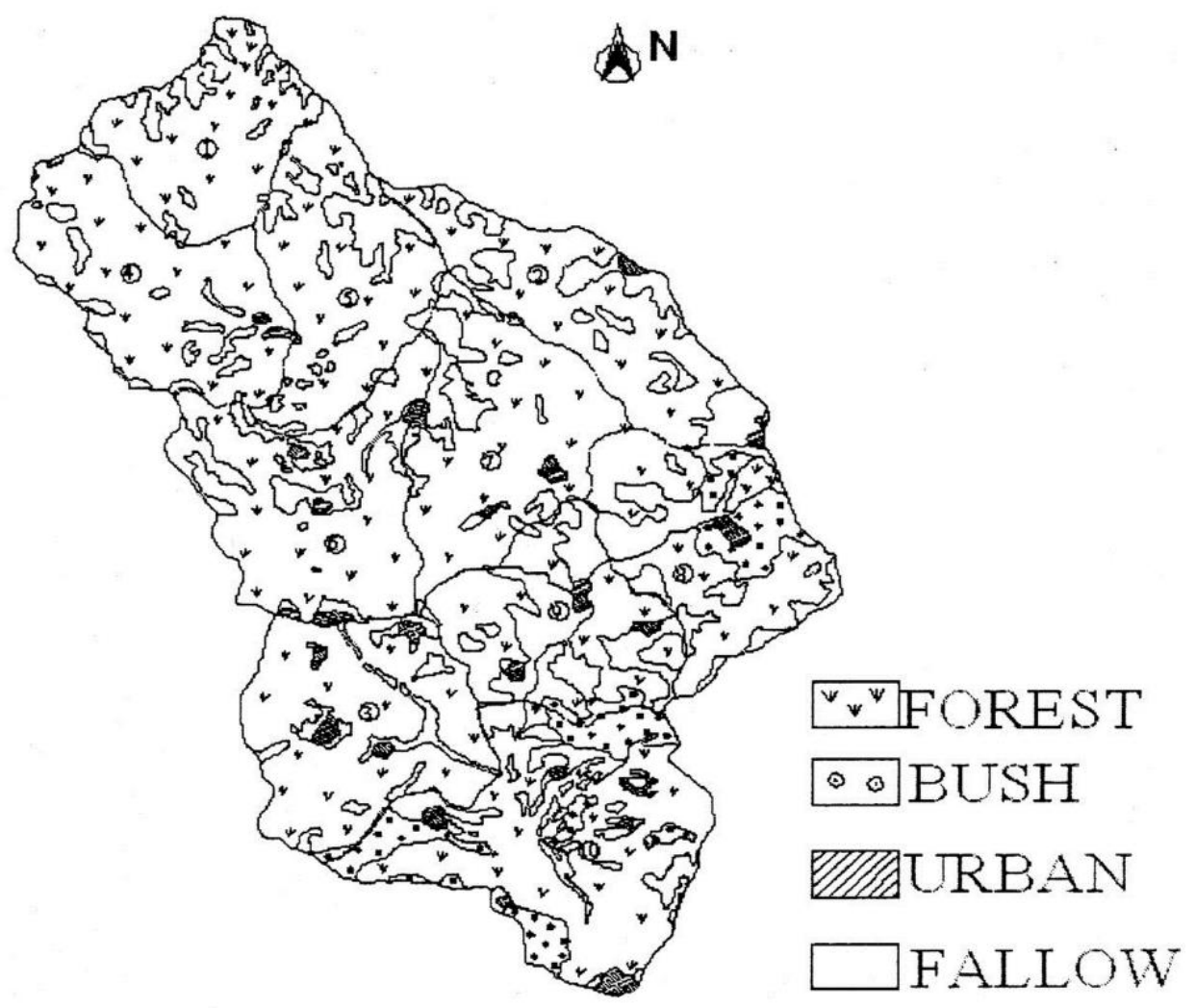

Figure 3. Soil cover map of Kosynthos River basin

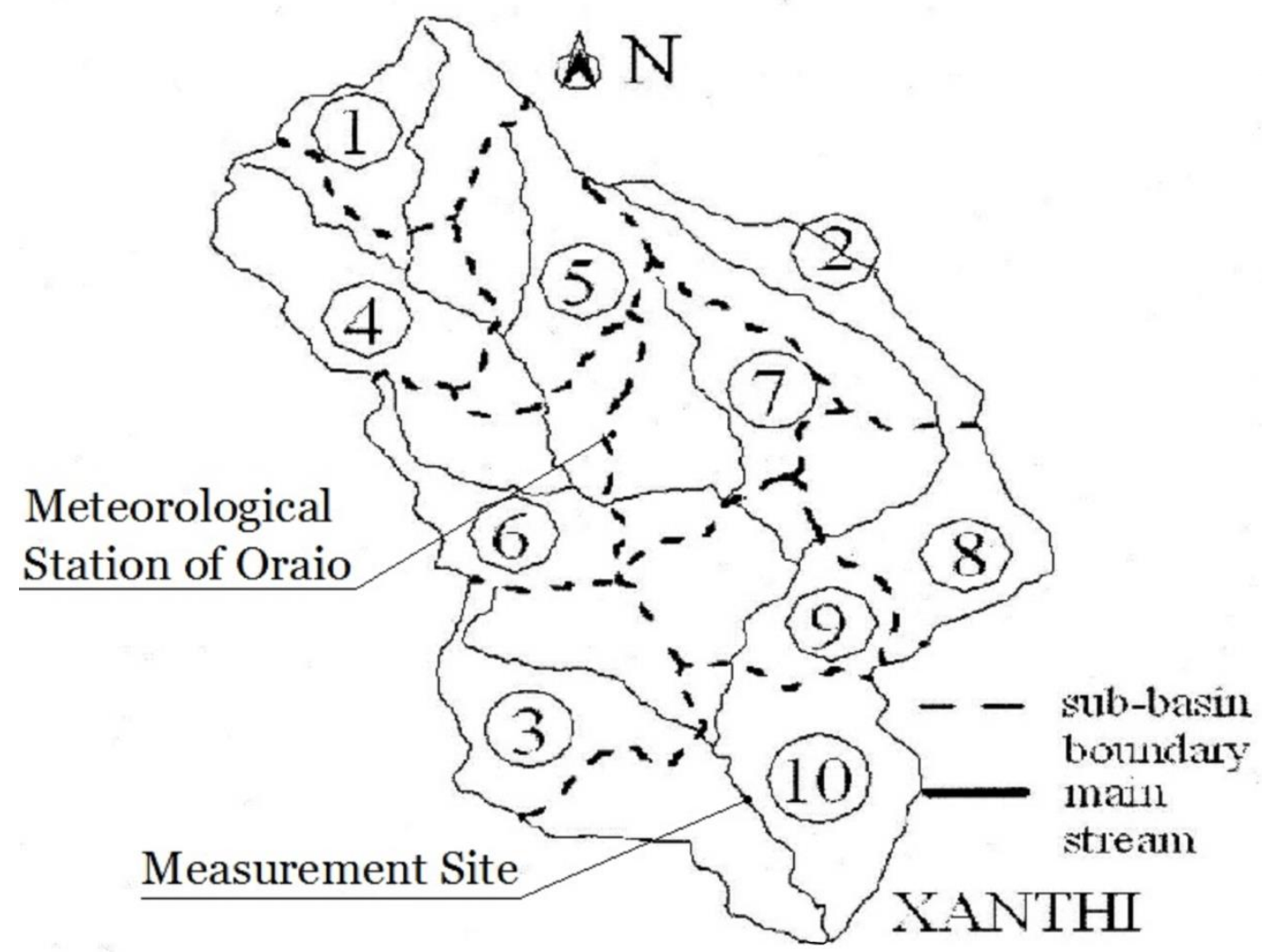

Figure 4. Map of the main streams of the ten sub-basins 


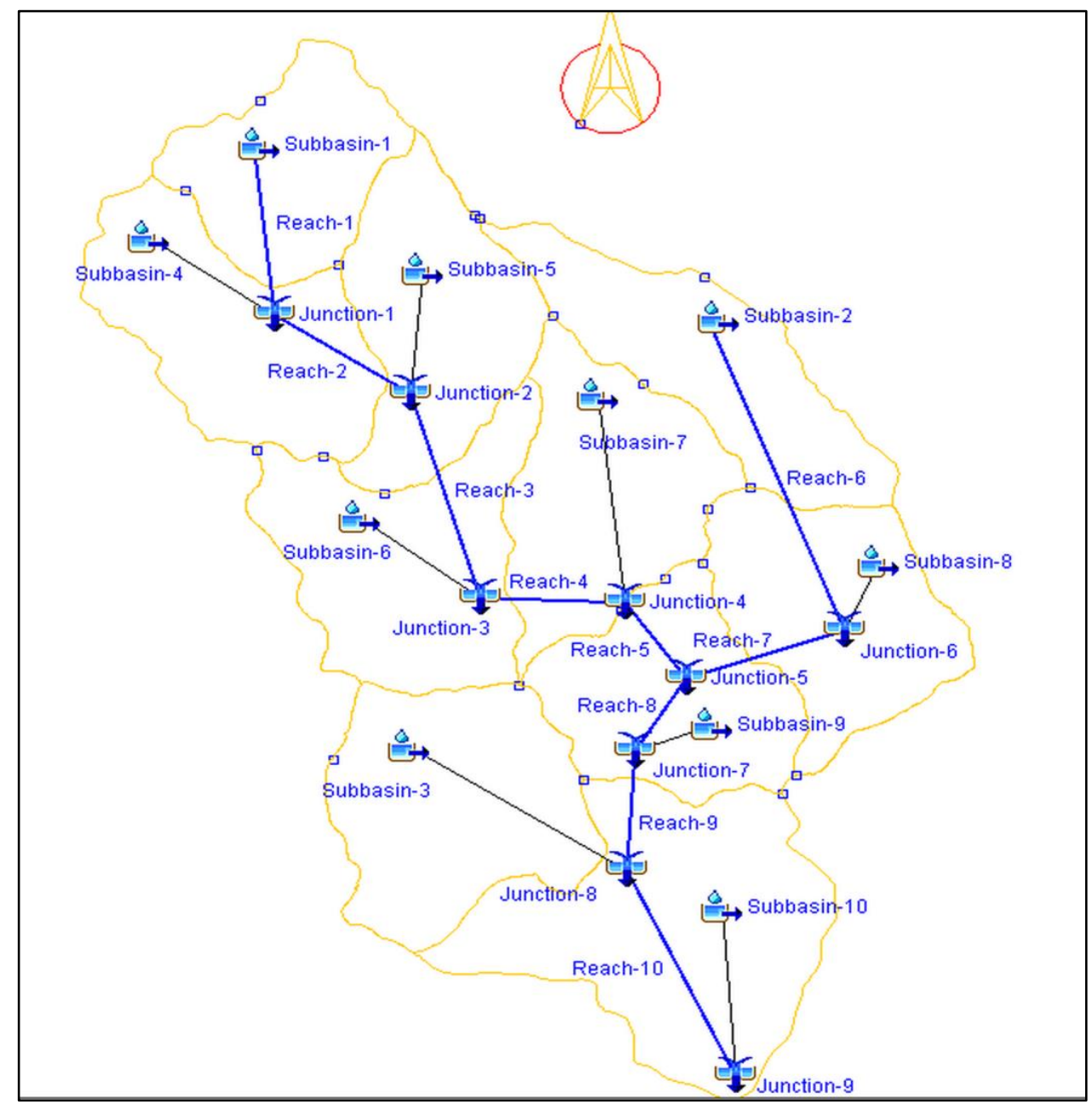

Figure 5. Basin structure for the model operation

\subsection{Determination of the model parameters}

A detailed determination of the parameter $\mathrm{CN}$ (curve number), included in the SCS rainfall excess model, was undertaken in this study, because the hydrologic model is very sensitive to the parameter $\mathrm{CN}$. The curve number was estimated for each sub-basin by processing the soil cover map and by using the disposable soil data for the basin. According to Gikas (2002), the entire soil surface of the basin consists of sandy clay and therefore resides in the hydrologic class $B$ (semipermeable soils). The curve number values were estimated for the medium soil moisture condition (CN II).

The parameter of the SCS model for the transformation of rainfall excess to runoff hydrograph, which has to be estimated, is the concentration time. The concentration time was computed by the formula of Turazza-Giandotti.

The determined parameters of the Muskingum-Cunge routing model are: a) the main stream length of each sub-basin (main stream map), b) the average slope of the main stream of each sub-basin (contour map), c) the geometric characteristics of the cross sections (estimated), d) the Manning coefficient depending on the roughness of the stream bed (estimated). At this point, it has to be noted that a sensitivity analysis for Manning coefficient showed that its value does not influence considerably the computed hydrographs.

In Table 1, the area, the curve number and the concentration time, resulting from the Giandotti formula, are given for each sub-basin. In Table 2, the length, the bed slope, the bottom width, the shape of the cross section and the Manning coefficient are given for each routing reach. 
Table 1. Area, curve number and concentration time values for each sub-basin

\begin{tabular}{cccc}
\hline Sub-basin & Area $\left(\mathrm{km}^{2}\right)$ & Curve number & Concentration time (min) \\
\hline 1 & 17.58 & 63.55 & 129 \\
\hline 2 & 21.53 & 67.36 & 171 \\
\hline 3 & 25.79 & 64.35 & 276 \\
\hline 4 & 23.68 & 63.06 & 102 \\
\hline 5 & 21.93 & 65.59 & 108 \\
\hline 6 & 25.43 & 65.98 & 353 \\
\hline 7 & 23.33 & 65.07 & 101 \\
\hline 8 & 22.18 & 67.28 & 104 \\
\hline 9 & 20.48 & 70.04 & 133 \\
\hline 10 & 35.35 & 69.45 & 394 \\
\hline
\end{tabular}

Table 2. Length, bed slope, bottom width, cross section shape and Manning coefficient

\begin{tabular}{cccccc}
\hline $\begin{array}{c}\text { Routing } \\
\text { reach }\end{array}$ & $\begin{array}{c}\text { Reach } \\
\text { length }(\mathrm{m})\end{array}$ & $\begin{array}{c}\text { Reach bed } \\
\text { slope }\end{array}$ & $\begin{array}{c}\text { Bottom } \\
\text { width }(\mathrm{m})\end{array}$ & $\begin{array}{c}\text { Cross section } \\
\text { shape }\end{array}$ & $\begin{array}{c}\text { Manning coefficient } \\
\left(\mathrm{s} \mathrm{m}^{-1 / 3}\right)\end{array}$ \\
\hline 1 & 3930 & 0.0637 & 30 & rectangular & 0.12 \\
\hline 2 & 2320 & 0.0216 & 30 & rectangular & 0.12 \\
\hline 3 & 3740 & 0.0401 & 20 & rectangular & 0.12 \\
\hline 4 & 2960 & 0.0169 & 20 & rectangular & 0.12 \\
\hline 5 & 2000 & 0.0238 & 50 & rectangular & 0.12 \\
\hline 6 & 2000 & 0.0238 & 50 & rectangular & 0.12 \\
\hline 7 & 4720 & 0.0212 & 50 & rectangular & 0.12 \\
\hline 8 & 4200 & 0.0238 & 50 & rectangular & 0.08 \\
\hline 9 & 1000 & 0.0112 & 80 & rectangular & 0.08 \\
\hline 10 & 8910 & 0.0112 & 80 & rectangular & 0.08 \\
\hline
\end{tabular}

A "manual" calibration was carried out for the parameters that cannot be determined by means of tables and/or maps. Thus, the decay constant $k$ of the baseflow model has obtained the value 0.88 , while the threshold discharge was determined as equal to $25 \%$ of the peak discharge.

\section{QUANTITATIVE RESULTS}

In Figures 6, 7, 8, 9 and 10, the computed discharge hydrograph (direct runoff + baseflow) and the measured discharge values at the basin outlet are depicted for the periods October-December 2005, May-July 2006, March-April 2007, May-July 2008 and September 2008-January 2009, respectively. The arithmetic values in Figures 6-10 refer to the measured discharge values. In Table 3, the precise measured discharge values along with the calculated ones are given for each date. 


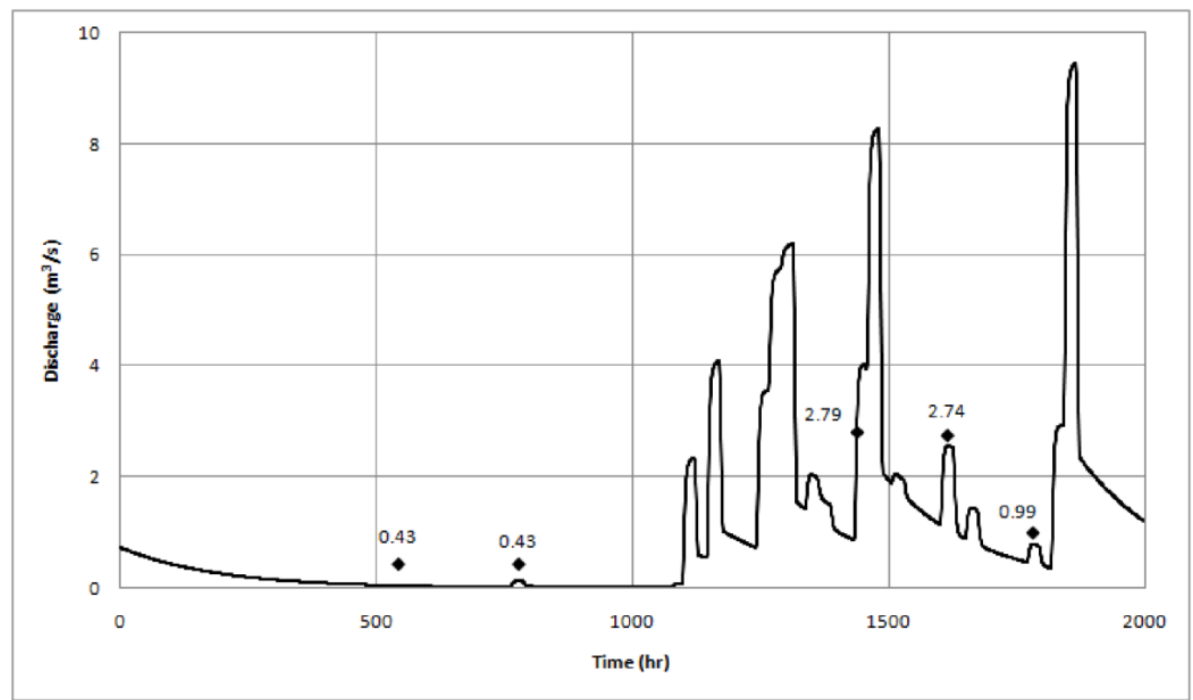

Figure 6. Discharge hydrograph of October - December 2005

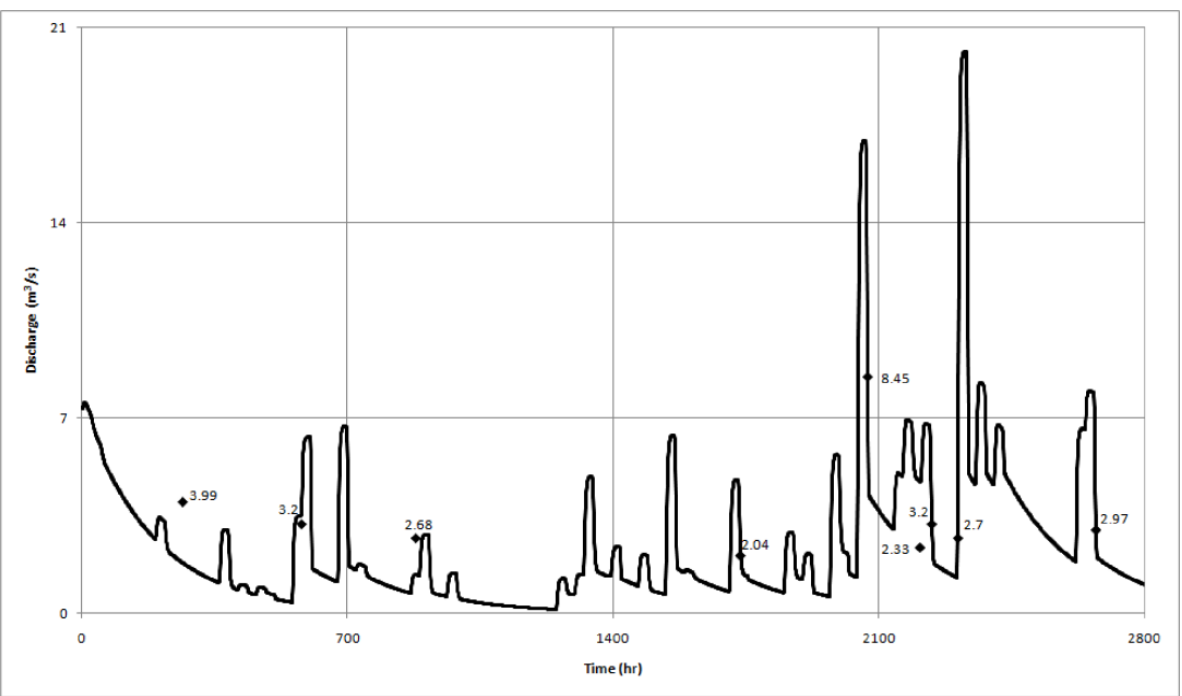

Figure 7. Discharge hydrograph of March - July 2006

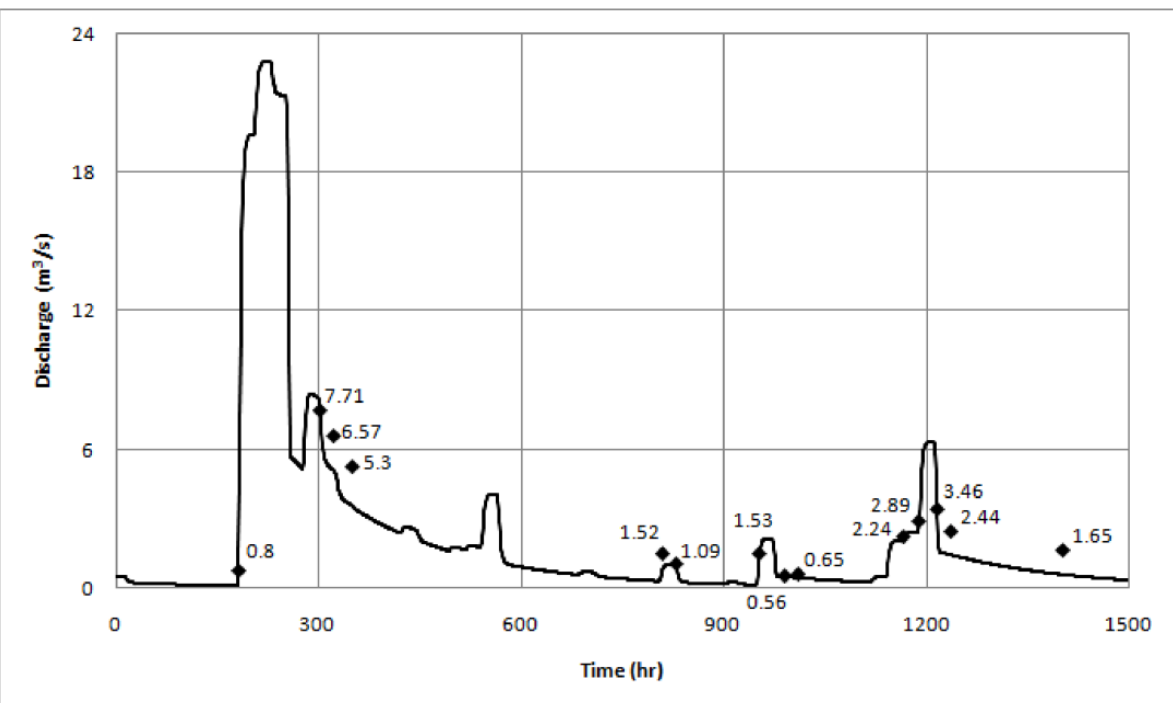

Figure 8. Discharge hydrograph of March - May 2007 


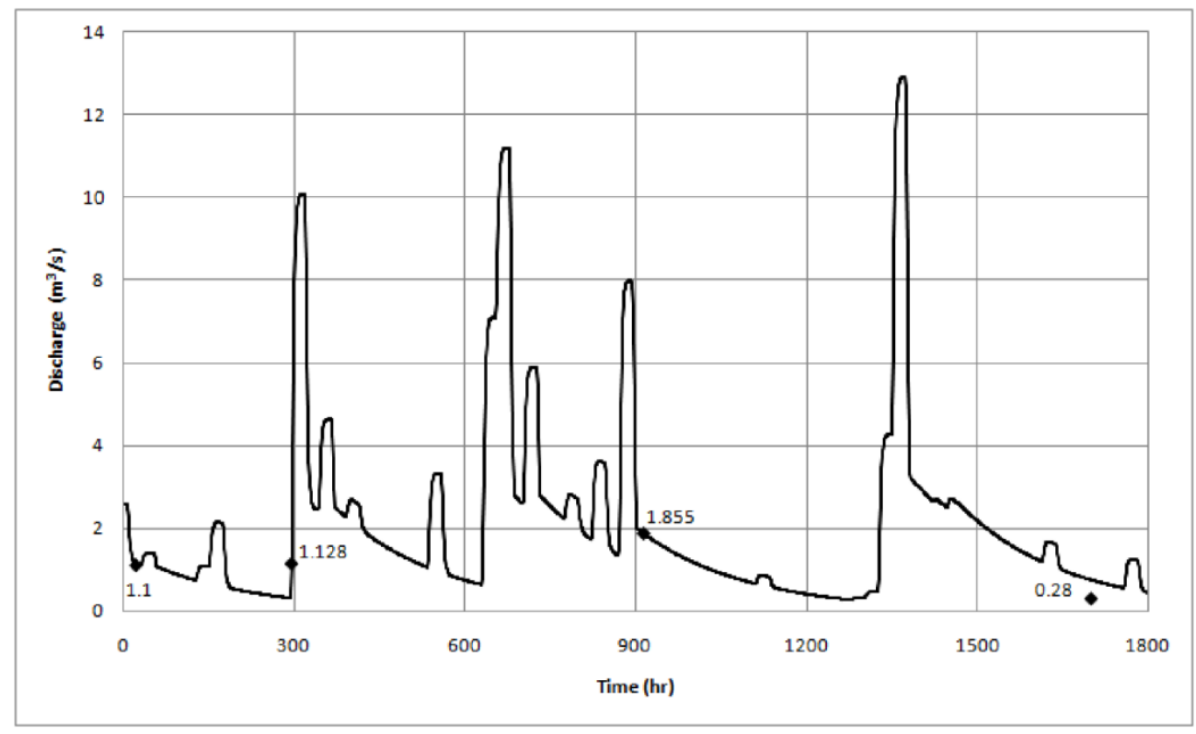

Figure 9. Discharge hydrograph of May - July 2008

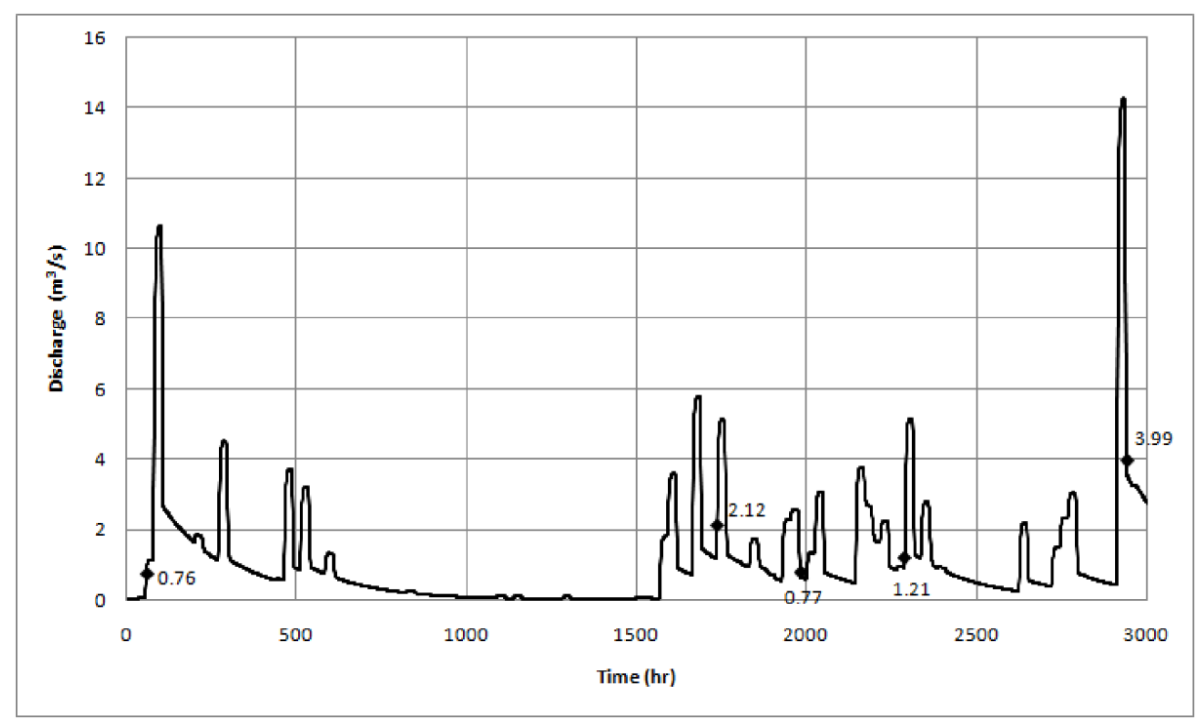

Figure 10. Discharge hydrograph of September 2008 - January 2009

According to Figures 7, 9 and 10, peak discharge values were not measured, while, according to Figures 6 and 8 , some peak discharge values were measured. At this point, it must be noted that it is practically impossible to measure the maximum peak discharge value of a long time period.

\section{COMPARISON BETWEEN COMPUTED AND MEASURED DISCHARGE VALUES}

Efficiency criteria are commonly used by hydrologists to provide an objective assessment of the "closeness" of the simulated behaviour to the observed measurements (Krause et al., 2005). For the comparison between computed and measured discharge values, the following criteria were used: "root mean square error" (RMSE), relative error, Nash-Sutcliffe efficiency coefficient, correlation coefficient $R$ and t-test.

RMSE $\left(\mathrm{m}^{3} \mathrm{~s}^{-1}\right)$ is defined mathematically as follows:

RMSE $=\sqrt{\frac{1}{n} \sum_{i=1}^{n}\left(O_{i}-P_{i}\right)^{2}}$

where 
$\mathrm{O}_{\mathrm{i}}$ : observed mean daily discharge for the day $\mathrm{i}\left(\mathrm{m}^{3} \mathrm{~s}^{-1}\right)$

$P_{i}$ : predicted mean daily discharge for the day $i\left(\mathrm{~m}^{3} \mathrm{~s}^{-1}\right)$

$\mathrm{n}$ : number of pairs of observed and predicted discharge values.

The value of RMSE amounts to $0.68 \mathrm{~m}^{3} \mathrm{~s}^{-1}$.

The relative error (\%) is expressed as

relative error $=\frac{O_{i}-P_{i}}{O_{i}} \times 100$

The relative error varies between the values $-90.7 \%$ and $166.79 \%$.

The efficiency E proposed by Nash and Sutcliffe (1970) is expressed by the following equation:

$E=1-\frac{\sum_{i=1}^{n}\left(O_{i}-P_{i}\right)^{2}}{\sum_{i=1}^{n}\left(O_{i}-\bar{O}\right)^{2}}$

where

$\overline{\mathrm{O}}$ : observed overall mean daily discharge $\left(\mathrm{m}^{3} \mathrm{~s}^{-1}\right)$

The range of $E$ lies between 1 (perfect fit) and $-\infty$. Efficiency was found to be 0.84 .

The degree of linear dependence between computed and measured discharge values is expressed by the correlation coefficient $R$. This coefficient, as a result of linear regression analysis, is equal to 0.927 (Figure 11). In the same figure, the line of perfect agreement between computed and measured discharge values is shown.

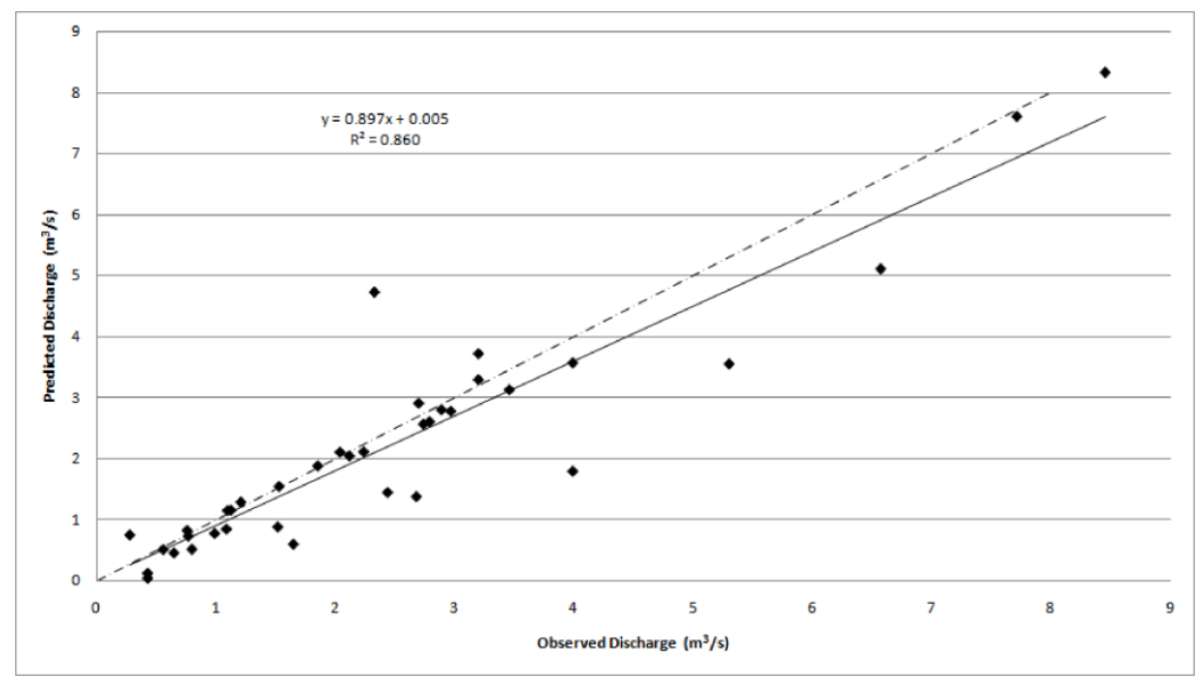

Figure 11. Linear regression line between computed and measured discharge values

A t-test has also shown that there is no statistically significant difference between the observed and predicted discharge values. 
Table 3. Measured and calculated discharges

\begin{tabular}{|c|c|c|c|}
\hline Date & $\begin{array}{c}\text { Measured } \\
\text { discharge }\left(\mathrm{m}^{3} \mathrm{~s}^{-1}\right)\end{array}$ & $\begin{array}{l}\text { Calculated } \\
\text { discharge } \\
\left(\mathrm{m}^{3} \mathrm{~s}^{-1}\right)\end{array}$ & $\begin{array}{l}\text { Ratio of measured to } \\
\text { calculated discharge }\end{array}$ \\
\hline 26 October 2005 & 0.43 & 0.04 & 10.75 \\
\hline 2 November 2005 & 0.43 & 0.12 & 3.55 \\
\hline 30 November 2005 & 2.79 & 2.60 & 1.07 \\
\hline 7 December 2005 & 2.74 & 2.56 & 1.07 \\
\hline 14 December 2005 & 0.99 & 0.77 & 1.28 \\
\hline 26 March 2006 & 3.99 & 1.79 & 2.23 \\
\hline 8 April 2006 & 3.20 & 3.71 & 0.86 \\
\hline 20 April 2006 & 2.68 & 1.38 & 1.95 \\
\hline 26 May 2006 & 2.04 & 2.10 & 0.97 \\
\hline 9 June 2006 & 8.45 & 8.32 & 1.02 \\
\hline 14 June 2006 & 2.33 & 4.72 & 0.49 \\
\hline 16 June 2006 & 3.20 & 3.29 & 0.97 \\
\hline 20 June 2006 & 2.70 & 2.90 & 0.93 \\
\hline 3 July 2006 & 2.97 & 2.77 & 1.07 \\
\hline 19 March 2007 & 0.80 & 0.51 & 1.56 \\
\hline 28 March 2007 & 7.71 & 7.60 & 1.02 \\
\hline 29 March 2007 & 6.57 & 5.10 & 1.29 \\
\hline 30 March 2007 & 5.30 & 3.55 & 1.49 \\
\hline 17 April 2007 & 1.52 & 0.88 & 1.73 \\
\hline 18 April 2007 & 1.09 & 0.85 & 1.29 \\
\hline 23 April 2007 & 1.53 & 1.54 & 0.99 \\
\hline 25 April 2007 & 0.56 & 0.51 & 1.10 \\
\hline 26 April 2007 & 0.65 & 0.46 & 1.43 \\
\hline 1 May 2007 & 2.24 & 2.11 & 1.06 \\
\hline 2 May 2007 & 2.89 & 2.80 & 1.03 \\
\hline 3 May 2007 & 3.46 & 3.13 & 1.11 \\
\hline 4 May 2007 & 2.44 & 1.44 & 1.69 \\
\hline 11 May 2007 & 1.65 & 0.60 & 2.76 \\
\hline 10 May 2008 & 1.10 & 1.15 & 0.96 \\
\hline 24 May 2008 & 1.13 & 1.15 & 0.98 \\
\hline 16 June 2008 & 1.86 & 1.88 & 0.99 \\
\hline 16 July 2008 & 0.28 & 0.75 & 0.37 \\
\hline 18 September 2008 & 0.76 & 0.82 & 0.92 \\
\hline 26 November 2008 & 2.12 & 2.04 & 1.04 \\
\hline 5 December 2008 & 0.77 & 0.73 & 1.06 \\
\hline 19 December 2008 & 1.21 & 1.29 & 0.94 \\
\hline 15 January 2009 & 3.99 & 3.57 & 1.12 \\
\hline
\end{tabular}

\section{CONCLUSIONS}

It is concluded that there is a very good approximation between the computed and measured discharge values and that the deviation between these values is not considerable. Additionally, the degree of linear dependence between computed and measured discharge values is very high. 
However, a small deviation between computed and measured discharge values is justified by the fact that the measurements were not carried out exactly at the basin outlet, but near the basin outlet. Consequently, through the continuous hydrologic modeling for a relatively long time period in a relatively large basin, a more realistic representation of the runoff process can be achieved. Additionally, the maximum peak values of the hydrographs can be computed.

An important component of a continuous hydrologic model is that of baseflow, for both time periods during and after the rainfall events. Therefore, a more realistic assumption for the time variation of baseflow was included in the hydrologic model (exponential recession of the initial baseflow value). However, the parameters of the baseflow component were determined by calibration in contrast to the other parameters of the hydrologic model that were determined by means of maps and/or relevant tables.

Finally, it is believed that the deviations between computed and measured discharge values for single rainfall events can be mitigated by means of the continuous hydrologic modeling, because of the integrating effect obtained through use of a long simulation period.

\section{REFERENCES}

Allen R.G., Pereira L.S., Raes D. and Smith M. (1998). Crop Evapotranspiration: Guidelines for Computing Crop Requirements. FAO Irrigation and Drainage Paper No. 56, FAO, Rome, Italy.

Angelidis P., Mystakidis G., Lalikidou S., Hrissanthou V. and Kotsovinos N. (2010), Computation of Hydrographs in Evros River Basin, European Water, 31, 33-42.

Beven K. (2004), Robert E. Horton's perceptual model of infiltration processes, Hydrological Processes, 18, 3447-3460.

Chow V.T., Maidment D.R. and Mays L.W. (1988). Applied Hydrology. McGraw-Hill Book Company. N.Y.

Chu X. and Steinman A.D. (2009), Event and Continuous Hydrologic Modeling with HEC-HMS, Journal of Irrigation and Drainage Engineering (ASCE), 135, 119-124.

Crawford N.H. and Linsley R.K. (1966). Digital simulation in hydrology. Stanford Watershed Model IV. Stanford University Technical Report No. 39, Stanford University, Palo Alto, CA.

Cunderlik J.M. and Simonovic, S.P. (2005), Hydrological extremes in a southwestern Ontario river basin under future climate conditions, Hydrological Sciences Journal, 50, 631-654.

Daniil E.I., Michas S.N. and Lazaridis L.S. (2005), Hydrologic Modeling for the Determination of Design Discharges in Ungauged Basins, Global Nest Journal, 7(3), 296-305.

Dinpashoh Y., Jhajharia D., Fakheri-Fard A., Singh V.P. and Kahya E. (2011), Trends in reference evapotranspiration over Iran, Journal of Hydrology, 399, 422-433.

Dooge J.C.I., Strupczewski W.G. and Napiorkowski J.J. (1982), Hydrodynamic derivation of storage parameters of Muskingum model, Journal of Hydrology 54, 371-387.

Dooge J.C.I. (1957), The rational method for estimating floods peak, Engineering, 184, 311-374.

Dooge J.C.I. (1959), A general theory of the unit hydrograph, Journal of Geophysical Research, 64(2), 241-256.

Doorenbos J. and Pruitt W.O. (1977). Crop water requirements. FAO Irrigation and Drainage Paper 24, Rome, Italy.

Džubáková K. (2010), Rainfall-Runoff Modelling: Its Development, Classification and Possible Applications, Acta Geographica Universitatis Comenianae, 54(2), 173-181.

Eagleson P.S., Mejia R. and March F. (1965). The computation of the optimum realizable unit hydrographs from rainfall and runoff data. Hydrodynamics Laboratory Report 84, MIT.

Espey, Huston \& Associates (1987), Inc. (EHA). Drainage Criteria Manual for Fort Bend Country, Huston, Texas.

Fleming M. and Neary V. (2004), Continuous Hydrologic Modeling Study with the Hydrologic Modeling System, Journal of Hydrologic Engineering (ASCE), 9, 175-183.

Frevert D.K. and Singh V. (eds.) (2006). Watershed Models. Boca Raton: Taylor \& Francis Group, 653 p., ISBN 0-8493-3609-0.

Giandotti M. (1934). Forecast from full and lean courses of water. Ministry LL.PP., Hydrographic survey, Vol. 8, Rep. No. 2, Hydrographic Department of Italy, Rome (In Italian). 
Gikas G. (2002). Investigation of the aquatic ecosystem of Vistonis Lake. PhD dissertation, Department of Civil Engineering, Democritus University of Thrace, Xanthi, Greece (in Greek).

Keefer T.N. and McQuivey R.S. (1974), Multiple linearization flow routing model, Journal of the Hydraulics Division (ASCE), 100(7), 1031-1046.

Kent K. (1972). Travel Time, Time of Concentration and Lag. National Engineering Handbook, Section 4, Hydrology, Chapter 15.

Kerby W. S. (1959), Time of concentration for overland flow, Civil Engineering, 29(3), 60.

Kirpich Z.P. (1940), Time of concentration of small agricultural watersheds, Civil Engineering, 10(6), 362.

Krause P., Boyle D.P. and Bäse F. (2005), Comparison of different efficiency criteria for hydrological model assessment, Advances in Geosciences, 5, 89-97.

McEnroe B.M. (2010). Guidelines for Continuous Simulation of Streamflow in Johnson County, Kansas with HEC-HMS. Department of Civil, Environmental and Architectural Engineering, Univ. of Kansas.

Nash J.E. and Sutcliffe J.V. (1970), River flow forecasting through conceptual models, Part I - A discussion of principles, Journal of Hydrology, 10, 282-290.

Nasri M., Soleimani Sardoo F. and Katani M. (2011). Simulation of the Rainfall-Runoff Process Using of HEC-HMS Hydrological Model (A Case Study of Sheikh Bahaei Dam Basin). World Academy of Science, Engineering and Technology 78.

Nearing M.A., Liu B.Y., Risse L.M. and Zhang X. (1996), Curve Numbers and Green-Ampt Effective Hydraulic Conductivities, Water Resources Bulletin (AWRA), 32(1), 125-136.

Neary V.S., Habib E. and Fleming M. (2004), Hydrologic Modeling with NEXRAD Precipitation in Middle Tennessee, Journal of Hydrologic Engineering (ASCE), 9, 339-349.

Prasad R. (1967), A non linear hydrologic systems response model, Journal of the Hydraulics Division, (ASCE), 4, 105-120.

Price R.K. (1973). Variable parameter diffusion method for flood routing, Rep. no INT 115. Hydraulic Research Station, Wallingford, UK.

Scharffenberg W., Ely P., Daly S., Fleming M. and Pak J. (2010). Hydrologic Modeling System (HECHMS): Physically-Based Simulation Components. 2nd Joint Federal Interagency Conference, June 27-July 1, Las Vegas, NV.

Sharma K.D., Sorooshian S., Wheater H. (eds.) (2008). Hydrological Modelling in Arid and Semi-Arid Areas. New York: Cambridge University Press, 223 p., ISBN-13 978-0-511-37710-5.

Sherman L.K. (1932), Streamflow from rainfall by the unit graph method, Engineering News Record, 108: 501-505.

Soil Conservation Service (SCS) (1993). Hydrology. National Engineering Handbook, Supplement A, Section 4, Chapter 10, USDA, Washington DC, USA.

Tikhonov A.N. (1963), Regularization of incorrectly posed problems, Soviet Mathematics, 4, 1624-1627.

Todini E. and Wallis J.R. (1977). Using CLS for daily or longer period rainfall-runoff modelling. In Mathematical models for surface water hydrology, Ciriani T.A., Maione U. and Wallis J.R.(eds), J. Wiley: London, UK.

Tsakiridis P., Ziogas K. and Hrissanthou V. (2007). Application of a continuous rainfall-runoff model to the basin of Kosynthos River. In: Water Resources Management: New Approaches and Technologies, EWRA Symposium, Chania, Crete, 203-210.

United States Army Corps of Engineers (USACE) (2010). Hydrologic Modeling System HEC-HMS. User's Manual, Version 3.5. Hydrologic Engineering Center.

Verstraeten W.W., Muys B., Feyen J., Veroustraete F., Minnaert M., Meiresonne L. and De Schrijver A. (2005), Comparative analysis of the actual evapotranspiration of Flemish forest and cropland, using the soil water balance model WAVE, Hydrology and Earth System Sciences, 9, 225-241.

Walker S.E,, Banasik K,, Northcott W.J,, Jiang N,, Yuan Y. and Mitchell J.K. (2001). Application of the SCS Curve Number Method to Mildly-Sloped Watersheds, In: Southern Cooperative Series Bulletin 398, John E. Parsons, Daniel L. Thomas, Rodney L. Huffman (eds.)

Wiener N. (1949). The Extrapolation, Interpolation and Smoothing of Stationary Time Series, The Technology Press of MIT and J. Wiley, New York, 163. 